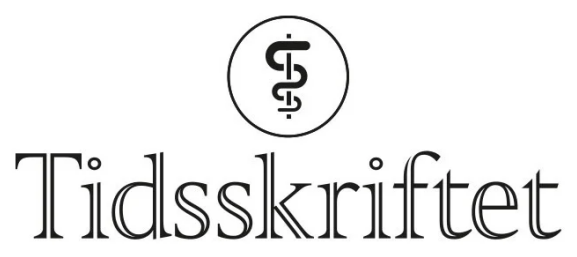

DEN NORSKE LEGEFORENING

\title{
Når minuttene teller
}

\author{
NOE Å LAERE AV
}

ANNE HEGE AAMODT

Anne Hege Aamodt (f. 1972) er spesialist i nevrologi og overlege.

Forfatter har fylt ut ICMJE-skjemaet og oppgir følgende interessekonflikter: Hun har mottatt foredragshonorar fra Pfizer og Boehringer Ingelheim og møtegodtgjørelse fra sistnevnte. Email: anne.hege.aamodt@ous-hf.no

Klinikk for kirurgi og nevrofag

Oslo universitetssykehus, Rikshospitalet

Opptil halvparten av dem som innlegges med spørsmål om hjerneslag, har helt andre diagnoser (1). For å kunne avklare diagnosen er både anamnese og nevrologisk undersøkelse nødvendig i tillegg til radiologiske undersøkelser. Med den kliniske undersøkelsen sorteres ofte andre diagnoser raskt ut, men CT/MR er nødvendig for å skille infarkt fra blødning. I en del tilfeller er også blodprøver nødvendig før beslutning om behandling kan tas. Den største utfordringen er at dette må foregå svært raskt for at man skal kunne gi effektiv behandling. Ved akutt hjerneinfarkt er intravenøs trombolytisk behandling foreløpig eneste godkjente reperfusjonsbehandling. Tidsvinduet er 4,5 timer, og effekten avtar dramatisk i løpet av dette tidsvinduet. Kai Ivar Müller og medarbeidere gir en grundig og ryddig gjennomgang av sykehistorien til en pasient med tilsynelatende vanlige slagsymptomer, men som viste seg å ha en sjelden tilstand som krever rask avklaring og behandling - spinalt epiduralt hematom. I artikkelen problematiseres dilemmaet med å gjøre diagnostikken presis nok, men allikevel iverksette adekvat behandling tidsnok.

Spinalt epiduralt hematom er en blodansamling i epiduralrommet som kan gi mekanisk kompresjon mot medulla spinalis med myelopati. Tidlig diagnostikk og rask kirurgisk behandling med dekompresjon av hematomet bedrer sjansene for godt resultat (므)-(4). Tilstanden forekommer sjelden og opptrer hyppigst spontant, men kan også komme etter traume, fysisk aktivitet, kirurgisk inngrep, spinalpunksjon, spinal kiropraktorbehandling, ved koagulasjonsforstyrrelser og ved vaskulære malformasjoner $(\underline{2}, 5)$. Debutsymptomene er typisk akutte og uttalte smerter i nakke (coup de poignard) med eller uten utstråling til ekstremitetene. Smertene etterfølges av nevrologiske utfall med paraparese eller tetraparese, sjeldnere hemiparese (므), Brown-Séquard-liknende bilde (7.) eller spinalis anterior-syndrom. L'Hermittes tegn kan være en nyttig ledetråd ( $\underline{6})$.

Müller og medarbeidere drøfter godt de potensielle fallgruvene i utredningen av pasienter med akutte nevrologiske symptomer som likner på hjerneslag. Forfatterne gir en åpen og systematisk gjennomgang av hvordan de kom frem til diagnosen og deretter fikk iverksatt rask kirurgisk behandling hos denne pasienten med spinalt epiduralt hematom. 
Nakkesmerter, alternerende hemiparese og tetraparese, samt fravær av hjernenerveutfall var viktige ledetråder for å finne frem til lesjonen cervikotorakalt, men bildeundersøkelser var nødvendig for å komme frem til sikker diagnose (모). Klinikere som driver med intravenøs trombolytisk behandling ved akutt hjerneslag bør kjenne til denne tilstanden som kontraindikasjon mot slik behandling.

\section{LITTERATUR}

1. Thomassen L, Waje-Andreassen U, Næss $\mathrm{H}$ et al. Behandling av cerebrovaskulære sykdommer i slagenhet. Tidsskr Nor Legeforen 2011; 131: 819-23. [PubMed]

2. Liou KC, Chen LA, Lin Y]. Cervical spinal epidural hematoma mimics acute ischemic stroke. Am J Emerg Med 2012; 30: 1322.e1-3.

3. Hussenbocus SM, Wilby MJ, Cain C et al. Spontaneous spinal epidural hematoma: a case report and literature review. J Emerg Med 2012; 42: e31-4. [PubMed] [CrossRef]

4. Shin JJ, Kuh SU, Cho YE. Surgical management of spontaneous spinal epidural hematoma. Eur Spine J 2006; 15: 998-1004. [PubMed] [CrossRef]

5. Solheim O, Jørgensen JV, Nygaard OP. Lumbar epidural hematoma after chiropractic manipulation for lower-back pain: case report. Neurosurgery 2007; 61: E170-1. [PubMed] [CrossRef]

6. Matsumoto H, Miki T, Miyaji Y et al. Spontaneous spinal epidural hematoma with hemiparesis mimicking acute cerebral infarction: two case reports. J Spinal Cord Med 2012; 35: 262-6. [PubMed] [CrossRef]

7. Cai HX, Liu C, Zhang JF et al. Spontaneous epidural hematoma of thoracic spine presenting as Brown-Séquard syndrome: report of a case with review of the literature. J Spinal Cord Med 2011;34: 432-6. [PubMed] [CrossRef]

8. Schmidley JW, Mallenbaum S, Broyles K. Spinal epidural hematoma: an important stroke mimic. Acute Med 2013; 12:30-3. [PubMed]

Publisert: 25. juni 2013. Tidsskr Nor Legeforen. DOI: 10.4045/tidsskr.13.0627

Mottatt 2.5. 2013, første revisjon innsendt 4.6. 2013, godkjent 4.6. 2013. Medisinsk redaktør Merete Kile Holtermann.

(C) Tidsskrift for Den norske legeforening 2023. Lastet ned fra tidsskriftet.no 26. april 2023. 